\title{
The activities of regional municipal solid waste operators in modern conditions
}

\author{
N.V. Bushueva, T.S. Sobol, N.V. Sergeeva, and M.S. Fedorova* \\ Moscow Witte University, 2nd Kozhukhovsky passage, 12, buil. 1, 115432 Moscow, Russia
}

\begin{abstract}
The research involves analysis of the macroeconomic indicators of the activities of regional solid municipal waste operator in the Lipetsk region, identifying the most attractive areas for operating as a regional solid municipal waste operator developing proposals to improve the financial condition of one of the regional operators on the example of LLC RMK. The authors compare and analyze the economic parameters of the activities of regional solid municipal waste operators in the Lipetsk region. The main reasons for the decrease in the profitability of regional solid municipal waste operators are identified, the main tasks of reforming the waste management sector in the Russian Federation are formulated, measures are proposed to increase the financial stability and economic attractiveness of the regional operator.
\end{abstract}

\section{Introduction}

The relevance of the research topic lies in the fact that the financial efficiency of any organization in the modern context of economic formation largely depends on the properly chosen strategy and tactics of marketing management. Particularly important, both from an economic and social point of view, is the strategic planning of enterprises in the municipal solid waste management (hereinafter - MSW), which have become regional operators, in the course active reform of this industry, as well as intensively changing legislation. These conditions urgently require forming an appropriate strategy for the organization and predicting the further development of the economic situation to maintain the attractiveness of the company and business in general. An analysis of the attractiveness of an organization provides insight into the structure and dynamics of the municipal solid waste management industry, its characteristic opportunities and existing threats, identifies key success factors and, on this basis, develop a strategy for the company's behavior in the economic market. Considering the positive or negative assessments of the industry, a list of opportunities and threats for the organization is formed in order to be used later in the SWOT analysis. On the basis of these and other indicators, in general, the industry attractiveness is assessed in terms of a specific organization: whether it is advisable to enter a new business, whether it makes sense to strengthen the competitive position in the current business, whether to start preparing for the exit from this industry, etc. All this determines the relevance of the research topic.

\footnotetext{
* Corresponding author: mfedorova@muiv.ru
} 
Issues related to the scientific and methodological substantiation of the methodology for developing a firm's strategy and proposals to increase its attractiveness in the context of a dynamically developing solid municipal waste management industry requires a more detailed study.

In 2018, in accordance with the requirements of legislation in waste management in the Lipetsk region, a competitive selection of regional municipal solid waste operators was held. In accordance with the provisions of the territorial scheme for waste management, including solid municipal waste, the Lipetsk region was divided into 4 zones, each of which underwent a competitive procedure.

The tender documentation for the selection of regional operators of the Lipetsk region included the mandatory conditions for the winner to fulfill the selection and key indicators of its future activities. These parameters have a direct impact on the formation of the financial and economic foundations of the company's activities, the preservation of its economic stability and further development.

\section{Materials and Methods}

The research involves analysis of the macroeconomic indicators of the activities of regional solid municipal waste operator in the Lipetsk region, identifying the most attractive areas for operating as a regional solid municipal waste management operator developing proposals to improve the financial condition of one of the regional operators on the example of LLC RMK.

To assess the activities of regional municipal solid waste operators in modern conditions, the authors used some indicators of the activities of regional municipal solid waste operators in the Lipetsk region, proposed ways for improving the MSW logistics scheme, as well as handling medical waste.

The article developed a medical waste handling procedure.

\section{Results and Discussion}

In the Lipetsk region, four companies have status of regional municipal solid waste operators in accordance with the division of the region into four service areas (center, Gryazinskaya, Eletskaya, and Severnaya).

Table 1. The share of services provided by regional municipal solid waste operators in the Lipetsk region [4]

\begin{tabular}{|l|c|c|}
\hline $\begin{array}{c}\text { Name of the service area of } \\
\text { regional operators }\end{array}$ & $\begin{array}{c}\text { Volume of services provided (in } \\
\text { kind), thousand tons }\end{array}$ & Share, \% \\
\hline center & 245.66 & 53.15 \\
\hline Gryazinskaya & 57.56 & 12.45 \\
\hline Eletskaya & 90.34 & 19.54 \\
\hline Severnaya & 68.67 & 14.86 \\
\hline Total for the region & 462.23 & 100.00 \\
\hline
\end{tabular}

Three factors affect the gross income from the population [1]:

1. The municipal solid waste accumulation standard. Approved by the authorized executive body of the constituent entity of the Russian Federation. In 2020 it is:

for the population living in individual residential buildings (IRB) - $2.7 \mathrm{~m} 3$ of municipal solid waste per person per year; 
for the population living in multiple dwelling units (MDU) - $2.04 \mathrm{~m} 3$ of solid municipal waste per person per year.

2. The number of residents registered in premises.

3. The ultimate unified tariff for the service of a regional solid municipal waste operator (approved by the executive authority of the constituent entity of the Russian Federation authorized in the area of tariff regulation).

Table 2. Values of the main factors of the value of gross revenue from the population $[5,7,9]$

\begin{tabular}{|l|c|c|c|c|c|c|}
\hline \multirow{2}{*}{$\begin{array}{c}\text { Name of the } \\
\text { service area of } \\
\text { regional } \\
\text { operators }\end{array}$} & $\begin{array}{c}\text { Accumulation } \\
\text { standard, } \\
\mathrm{m}^{3} \text { per person } \\
\text { per year }\end{array}$ & $\begin{array}{c}\text { Number } \\
\text { of } \\
\text { residents, } \\
\text { thousand } \\
\text { people }\end{array}$ & $\begin{array}{c}\text { Single tariff of a } \\
\text { regional } \\
\text { operator, } \\
\text { rub } / \mathrm{m}^{3}\end{array}$ & \multicolumn{2}{|c|}{$\begin{array}{c}\text { Maximument due, rub. } \\
\text { per person per } \\
\text { month }\end{array}$} \\
\cline { 2 - 3 } & MDU & IRB & MDU & IRB \\
\hline Tsentralnaya & 2.04 & 2.7 & 614.86 & 492.38 & 83.7 & 110.79 \\
\hline Gryazinskaya & 2.04 & 2.7 & 162.504 & 509.89 & 86.68 & 114.73 \\
\hline Eletskaya & 2.04 & 2.7 & 215.555 & 508.94 & 86.52 & 114.51 \\
\hline Severnaya & 2.04 & 2.7 & 151.116 & 541.55 & 92.06 & 121.85 \\
\hline
\end{tabular}

Since 2019, the solid municipal waste management service has been a public service [1]; both individuals and legal entities are clients of regional operators. The volume of services provided depends on the number of sources of solid municipal waste generation.

Table 3. The number of sources of solid municipal waste generation in the Lipetsk region, units [1]

\begin{tabular}{|c|c|c|c|c|}
\hline \multicolumn{4}{|c|}{ Name of the service area of regional operators } & \multirow{2}{*}{$\begin{array}{c}\text { Total for the } \\
\text { region }\end{array}$} \\
\hline Tsentralnaya & Gryazinskaya & Eletskaya & Severnaya & \\
\hline $1,630,220$ & 318,048 & 484,916 & 404,352 & $2,837,536$ \\
\hline
\end{tabular}

The formation of a regional operator's activity strategy also depends on the projected values. In the Lipetsk region, the following projected values of the generation of solid municipal waste (respectively, the volume of services) have been established.

Table 4. The projected generation of solid municipal waste in the Lipetsk region until 2030 (thousand tons) [1]

\begin{tabular}{|l|c|c|c|c|c|c|}
\hline $\begin{array}{c}\text { Name of the service area of } \\
\text { a regional operator }\end{array}$ & 2019 & 2020 & 2024 & 2028 & 2030 & $\begin{array}{c}\text { Share (2030), } \\
\%\end{array}$ \\
\hline Tsentralnaya & 246 & 246 & 247 & 249 & 249 & 53.09 \\
\hline Gryazinskaya & 58 & 58 & 58 & 58 & 58 & 12.37 \\
\hline Eletskaya & 90 & 90 & 91 & 91 & 92 & 19.62 \\
\hline Severnaya & 69 & 69 & 69 & 69 & 70 & 14.92 \\
\hline Total for the region & 463 & 463 & 464 & 468 & 469 & 100 \\
\hline
\end{tabular}

We have analyzed the activities of the regional operator LLC Regonalnaia Mnogoprofinaia Kompaniia, located in the Lipetsk region. The LLC RMK regional waste management operator (Severnaya), which we are considering, along with the LLC Chistyi Gorod regional operator (Gryazinskaya), has the lowest volume of services provided, while with the highest tariff, which is explained by the low population density in the serviced area, and long ways of waste transportation. The most attractive is Tsentralnaya, which includes the regional center, the city of Lipetsk. It has 4 times more sources of waste generation, but the waste transport cost is much lower. In addition, $60 \%$ of Tsentralnaya population are rural citizens, which municipal solid waste contains the largest amount of food waste and waste from garden plots, and the smallest amount of waste type that could be used as secondary material resources. 
LLC RMK in accordance with the protocol of the commission No. 3 "On the results of the competitive selection of a regional operator for the management of municipal solid waste in the territory of the Northern Lipetsk region" dated 04.23.2018, the Agreement "On the organization of activities for the management of solid municipal waste in the territory of Tsentralnaya zone of the Lipetsk region" unnumbered, dated 04.05.2018, concluded with the management of housing and communal services of the Lipetsk region, is a regional municipal solid waste operator in the territory of Severnaya zone of the Lipetsk region. Severnaya consists of the following municipal districts: Dankovsky, Dobrovsky, Krasninsky, Lebedyansky, Lev-Tolstovsky, and Chaplyginsky.

In accordance with the requirements of Article 24.6 of the Federal Law of June 24, 1998 No. 89-FZ "On production and consumption wastes", as well as the provisions of the above Agreement, the regional operator ensures the activities for the management of MSW (collection, transportation, processing, disposal, neutralization, and dumping of MSW) on the territory of Severnaya zone in accordance with the regional program in waste management, the territorial waste management scheme, including solid municipal waste, of the Lipetsk region, regulatory legal acts of the Russian Federation, the Lipetsk region and the said Agreement.

The results of the analysis show a positive financial result from the LLC RMK activities for the collection and transportation of waste in 2015-2018. In 2019, given the expansion of the service area on the territory of the Lipetsk region, with the beginning of its activity as a regional municipal solid waste operator in the territory of Severnaya zone of the Lipetsk region, the problem of a decrease in profitability was identified, which directly affects its economic attractiveness.

As a result of the study, the main reasons for the decline in the profitability of regional municipal solid waste operators have been identified. These should include:

1. Transition to state regulation of the cost of services for the management of solid municipal waste. This fact limits the annual growth in the cost of the service to no more than $3-4 \%$, regardless of the growth in the cost of goods and services purchased by the regional operator.

2. The value of standards for the accumulation of municipal solid waste. The indicator is approved by the regional authority in waste management and directly affects the formation of the payment of citizens. It is often underestimated, thus the regional operator provides free services in an increased volume.

3. Collection of fees for services rendered. State regulation has changed the formation of the cost of services for the management of solid municipal waste, which caused its growth. Consumers met this fact met with indignation, in some cases to a complete refusal to pay.

4. The number of residents (registered) in the serviced area of the regional operator. With the transition to the new system, the service fee began to be charged per person, and not per living space.

Three of the four factors listed above (1,2 and 4) do not depend on LLC RMK. The collection of fees is regulated by the work of the legal department. LLC RMK is carrying out a thorough work in this direction.

Considering the fact that the solid municipal waste management industry is going through its reform, there are no favorable forecasts for increasing the economic stability and economic attractiveness of the organization for the next two-three-year period. It is necessary to take urgent measures for the future to prevent a decline in the performance of the company.

As noted earlier, in 2019, there was an increase in the volume of services, the revenue indicators increased almost 4 times compared to 2015. The value of the net assets of LLC RMK as of 2019 exceeds the authorized capital (10 thousand rubles), which positively 
characterizes the financial condition of the enterprise in terms of this indicator. This ratio fully complies with the requirements of regulatory documents for the value of net assets.

Based on the activity data of LLC RMK, prior to the start of its activity as a regional municipal solid waste operator and in its first year, as expected, there was a decrease in net revenue and profitability. It depends, among other things, on the following factors: the activity has become regulated by the state; there was an obligation to provide services in an "unattractive" territory; resistance of the population to new conditions, which contributes to the risk of reduced collection of payments for services rendered.

Based on the results of an express analysis of the morphological composition of solid municipal waste of Severnaya zone of the Lipetsk region, the population density, the length of the waste transportation routes, the availability of waste management facilities at the organization, to improve the financial condition a proposal was made to organize a waste sorting line of up to 40 thousand tons of waste per year and purchase equipment for the disposal of medical waste which fall outside the scope of government regulation. Estimated data on the implementation of measures show the total financial result of 13.7 million rubles annually.

The key tasks of reforming the waste management sector in the Russian Federation are the introduction of waste sorting (separate collection) and its civilized processing [6], as simple disposal of waste is economically unfeasible (in other words, valuable secondary raw materials are buried in the ground) and requires the allocation of significant territories. Considering the fact of yearly growing waste generation, soon there will be no land plots for landfills. Thus, large megacities are already struggling with this. In addition, the residents themselves oppose the proximity to landfills. All this leads to the need for the construction of waste sorting lines (complexes).

To maintain the economic attractiveness of the company - a regional operator in modern conditions of reforming the industry of solid waste management, serious measures should be taken. It is necessary to develop the main directions for the formation and preservation of the economic attractiveness of an organization - a regional municipal solid waste operator to create a new model for the effective organization of the solid municipal waste management industry in the region.

The formation and preservation of the economic attractiveness of an organization - a regional municipal solid waste operator depends on several factors: legislative and managerial decisions of the authorities (regulatory and legal regulation of waste management, regional tariff policy, etc.) and the company's own strategy, which should include working with a client base, improving infrastructure, participating in special programs - supporting industry business.

In our opinion, LLC RMK needs a set of measures to improve strategic planning and increase the economic attractiveness of the company. Leaving the mission and goals of the organization's activities unchanged, we propose that LLC RMK adjust the existing strategy: in addition to the transportation and disposal of waste, include in this chain the stage of processing (sorting) waste. That is, it is necessary to add a new measure for the acquisition and operation of a waste sorting line to the existing system of strategic planning. This strategy will strengthen the position of LLC RM" in its industry, in addition, the company will not have to pay for services for mandatory waste processing to third parties. This event should be supported by the coordinating authorities, as it considers the requirements of the Environmental Safety Strategy of the Russian Federation until 2025.

Figure 1 shows the future solid municipal waste management procedure carried out by LLC RMK. 


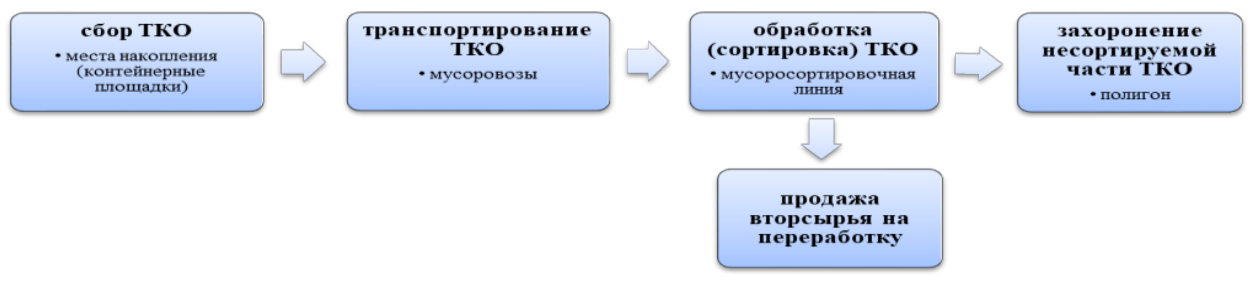

Fig. 1. The proposed MSW logistics scheme

Were: Сбор TКО - MSW collection; Места накопления (контейнерные площадки) - Points of accumulation (container sites); Транспортирование TKO - Transportation of MSW; Мусоровозы Garbage trucks; Обработка (сортировка) ТКО - MSW processing (sorting); Мусоросортировочная линия - Waste sorting line; Захоронение несортируемой части ТКО - Burial of unsorted MSW; Полигон - Landfill; Продажа вторсырья на переработку - Sale of recyclable waste for processing

The proposed solution is more likely to have social efficiency, as the profit received from the sale of recyclable materials will be considered when establishing a single tariff for the service of a regional operator for the next period and will serve to reduce its size, which in turn will have a favorable effect on the payment of citizens for the municipal solid waste handling.

At the same time, the amount freed up in a single tariff allows fully implementing investment programs, including, for example, the construction of landfills for waste disposal, the purchase of garbage trucks, the purchase of new equipment for sorting waste, etc., as well as replacing containers for municipal solid waste.

At the same time, we should note that after the expiration of the period of activity of LLC RMK as a regional operator, the studied organization will be able to continue its work as an operator, operating waste sorting equipment and thereby maintaining its business.

The economic attractiveness of an organization depends on its financial condition, the availability of material resources and a competent staff. If the last two factors of LLC RMK have positive characteristics, the financial condition, otherwise, worsens.

In order to increase the economic attractiveness of LLC RMK, it was proposed to enter new markets, namely medical waste management. Medical waste management is not a regulated activity and will help the organization in the event of force majeure to maintain business in an already studied industry. It is proposed to purchase specialized equipment - a medical waste incinerator.

The developed methodology includes the following stages:

Stage 1. According to the territorial scheme of waste management, including solid municipal waste, the Lipetsk region has determined the amount of medical waste for neutralization.

Stage 2. Considering the volume of medical waste for neutralization, we offer the HURIKAN 1000 incinerator manufactured by Eco-Spectrum. Incineration makes the waste safe and reduces its mass, as part of it is destroyed during incineration. The initial volume decreases by more than ten times.

Stage 3. The plant is quite mobile. It can be installed in the industrial settings of LLC RMK.

Stages 4 and 5. Using the manufacturer's information, the calculation of costs showed that the payback period of the initial investment ( 7.6 million rubles) for the purchase of equipment will be less than one year with an annual net profit of 10.75 million rubles.

Class A waste is not considered, as they are qualified as solid municipal waste in accordance with the sanitary and epidemiological legislation. Therefore, they fall under the responsibility of the regional operator. They can be disposed of at MSW landfills without preliminary treatment. The rest of the waste is subject to disposal at special facilities. 
Considering the volume of medical waste intended for neutralization, we offer to purchase Eco-Spectrum HURIKAN 1000 incinerator.

The main function of the incinerator is the safe disposal of waste through incineration of the organic part of the waste and evaporation of water. As a result, the initial volume of waste can be reduced significant (even more than 10 times). In addition, the waste is completely $(100 \%)$ decontaminated due to exposure to high temperatures. Due to the high combustion temperature (up to $1200^{\circ} \mathrm{C}$ ), the compounds are completely decomposed to the simplest components, which leads to a minimum content of pollutants in the exhaust gases. At the same time, destruction occurs in the installation - almost complete combustion of waste, the remainder in the form of ash is $3-5 \%$ of the original mass of waste. The resulting ash in most cases has a low hazard class for the environment and must be disposed of at MSW landfills.

Thus, despite the existing risks in its activities, LLC RMK has a fairly high development potential, and a particularly attractive scope of activity. Purposeful efforts and competent implementation of the proposed measures will allow LLC RMK to get out of the outlined economic recession and increase the level of economic attractiveness of the company to the previous values or even exceed them.

The set of solutions proposed for LLC RMK to improve strategic planning and increase the economic attractiveness of the company has social and economic efficiency; the annual financial result from the implementation of this plan is 13.65 million rubles, the expected increase in the profitability of the organization as a whole will be $22.6 \%$. Simultaneously with the achievement of these goals, LLC RMK can address environmental problems to reduce the negative impact of waste on the environment and human health.

The increase in the economic attractiveness of the company - a regional municipal solid waste operator - depends on the result of the competent implementation of the proposed measures.

Simultaneously with the solution of strategic tasks to increase the economic attractiveness of LLC RMK in the course of the measures, environmental tasks will be solved to reduce the negative impact of waste on the environment and human health.

\section{Conclusions}

The formation and preservation of the economic attractiveness of an organization - a regional municipal solid waste operator depends on several factors: legislative and managerial decisions of the authorities (regulatory and legal regulation of waste management, regional tariff policy, etc.) and the company's own strategy, which should include working with a client base, improving infrastructure, participating in special programs - supporting industry business. The increase in the economic attractiveness of the company - a regional municipal solid waste operator - depends on the result of the competent implementation of the proposed measures.

As part of this work, the activities of LLC RMK - a regional municipal solid waste operator in the Lipetsk region - were studied to formulate strategic directions in the development of the company and develop measures to increase its attractiveness.

The results of the study of the socio-economic and financial results of the activities of LLC RMK allow us to conclude about its sufficient economic sustainability. The economic indicators in recent years up to the end of 2018 showed stable growth. However, in connection with the start of activities of LLC RMK as a regional municipal solid waste operator in the territory of Severnaya zone of the Lipetsk region, the indicators of net profit and profitability showed a downward trend. The problem of reducing the company's profitability directly affects its economic attractiveness. 
As a result of the study, the main reasons for the decline in the profitability of regional municipal solid waste operators have been identified.

Considering the fact that the solid municipal waste management industry is going through its reform, there are no favorable forecasts for increasing the economic stability and economic attractiveness of the organization for the next two-three. It is necessary to take urgent measures for the future to prevent a decline in the performance of the company.

The results of the study of the socio-economic and financial results of the activities of LLC RMK allow us to conclude about its sufficient economic sustainability. The economic indicators in recent years up to the end of 2018 showed stable growth. However, in connection with the start of activities of LLC RMK as a regional municipal solid waste operator in the territory of Severnaya zone of the Lipetsk region, the indicators of net profit and profitability showed a downward trend.

In order to improve strategic planning and increase economic attractiveness under existing conditions, we have developed measures and methods for their implementation for LLC RMK.

We believe that these recommendations will help LLC RMK to return to its previous economic level and even improve its positions and, therefore, become one of the economically attractive companies in the waste management industry not only in the Lipetsk region, but also in Russian Federation.

Simultaneously with the solution of strategic tasks to increase the economic attractiveness of LLC RMK in the course of the measures, environmental tasks will be solved to reduce the negative impact of waste on the environment and human health.

\section{References}

1. On pricing in municipal solid waste management: Resolution of the Government of the Russian Federation of 30.05.2016 No. 484, http://www.consultant.ru/

2. On production and consumption waste: Federal Law of June 24, 1998 No. 89-FZ, http://www.consultant.ru/

3. On the approval of a comprehensive management strategy for solid municipal (household) waste in the Russian Federation: Order of the Ministry of Natural Resources and Environment of the Russian Federation dated 14.08.2013 No. 298, http://www.consultant.ru/

4. The territorial scheme of waste management, including solid municipal waste, the Lipetsk region, https://gkhlipetsk.ru/

5. Official statistical information, Lipetskstat, http://lipstat.gks.ru/

6. LLC RMK official website, http://rmk48.ru

7. Official site of the Lipetsk region administration for ecology and natural resources, http://ekolip.ru/

8. Official site of the Lipetsk region energy and tariffs administration, http://energy48.ru/

9. A.S. Kumara, A. Pallegedara, Waste Management, 114 (2020)

10. Rodriguez-Martin, R. Palomo-Zurdo, F. Gonzalez-Sanchez, Ciriec-Espana Revista De Economia Publica Social Y Cooperativa, 99 (2020)

11. G. Warth, A. Braun, O. Assmann, K. Fleckenstein, V. Hochschild, Remote Sensing, 12, $11(2020)$ 